\title{
Efektivitas Rambu Batas Kecepatan di Jalan Kolektor
}

\author{
${ }^{1}$ Yulianggi Trisya Pramesti, ${ }^{2}$ Anton Budiharjo \\ 1,2 Prodi Manajemen Keselamatan Transportasi Jalan, Politeknik Keselamatan Transportasi Jalan, Tegal, \\ Jawa Tengah, Indonesia \\ e-mail: anggitrisya64@gmail.com
}

\begin{abstract}
Abstrak
Salah satu penyebab terjadinya kecelakaan lalu lintas adalah ketidak patuhan pengemudi kendaraan bermotor untuk mematuhi batas kecepatan maksimal yang telah ditetapkan. Penelitian ini bertujuan menganalisis efektivitas rambu batas kecepatan maksimal yang telah terpasang di ruas Jalan Perintis Kemerdekaan, Kabupaten Cilacap dan memberi rekomendasi untuk meningkatkan efektivitas rambu batas kecepatan maksimal. Metode yang digunakan adalah survei langsung di lapangan dan analisis data uji T-Paired Sample Test, serta menilai efektivitas menggunakan N-Gain Score. Dari hasil analisis, didapatkan efektivitas rambu eksisting sebesar 6,25\%. Short-Term Memory berhubungan dengan apa yang dipikirkan seseorang ketika menerima stimulus dari lingkungan dengan durasi penyimpanan 15-20 detik. Durasi penyimpanan dapat meningkat hingga 20 menit apabila terdapat pengulangan informasi. Untuk meningkatkan efektivitas rambu batas kecepatan, maka dilakukan simulasi pemasangan rambu batas kecepatan secara berulang.
\end{abstract}

Kata kunci: Kecepatan; Manajemen Kecepatan; Keselamatan Jalan

\begin{abstract}
One of the causes of traffic accidents is the non-compliance of motorized vehicle drivers to comply with the maximum speed limits that have been set. This study discusses and analyzes the effectiveness of the maximum speed limit signs that have been installed on Jalan Perintis Kemerdekaan, Cilacap Regency and provides recommendations for increasing the effectiveness of the maximum speed limit signs. The method used is a direct survey in the field and data analysis of the T-Paired Sample Test, as well as assessing the effectiveness using the $\mathrm{N}$-Gain Score. From the analysis, it was found that the effectiveness of the existing signs was 6.25\%. Short-Term Memory is related to what a person thinks when receiving a stimulus from the environment with a storage duration of 15-20 seconds. The storage duration can increase up to 20 minutes if there is repetition of information. To increase the effectiveness of speed limit signs, a simulation of the installation of speed limit signs is carried out repeatedly.
\end{abstract}

Keywords: Speed; Speed Management; Road Safety

Diterima: 8 September 2020

Disetujui: 28 November 2020

Dipublikasi: 16 Desember 2020

(C2020 Yulianggi Trisya Pramesti, Anton Budiharjo Under the license CC BY-SA 4.0

\section{Pendahuluan}

Jalan Perintis Kemerdekaan, Kabupaten Cilacap merupakan jalan kabupaten dengan fungsi jalan kolektor primer dengan tipe 4/2 D, yang berarti memiliki 4 lajur dan 2 arah dan bermedian (terbagi). Memiliki panjang ruas jalan $1800 \mathrm{~m}$, dan lebar jalur 7,6 m serta per lajurnya 3,8 m. Volume lalu lintas tertinggi per arah yaitu 769,4smp/jam untuk arah Selatan ke Utara dan 1073,1 smp/jam untuk arah Utara ke Selatan. Dengan kondisi jalan demikian, maka sangat memungkinkan untuk pengguna jalan melaju dengan kecepatan tinggi saat melintas. 
Jalan Perintis Kemerdekaan merupakan salah satu lokasi rawan kecelakaan. Menurut data laka lantas Polres Kabupaten Cilacap, pada tahun 2015-2018 terdapat 36 kejadian kecelakaan lalu lintas yang terjadi di ruas jalan tersebut yang disebabkan oleh adanya pelanggaran batas kecepatan. Kecepatan kendaraan sendiri menjadi salah satu faktor yang perlu diperhatikan dalam mengemudikan kendaraan (Romadhona et al., 2017). Persepsi pengendara terhadap kecepatan mereka ditentukan oleh apa yang mereka lihat (Jongen et al., 2011)

Kecepatan yang ditetapkan pada suatu ruas jalan perkotaan maksimal $50 \mathrm{~km} / \mathrm{jam}$ (Peraturan Menteri Perhubungan Republik Indonesia Nomor 111, 2015). Tetapi pada umumnya pengendara kendaraan bermotor melajukan kendaraanya dengan kecepatan yang melebihi batas ketentuan yang telah ditetapkan (Kawulur et al., 2013) Faktor-faktor yang menentukan pengendara dalam menggunakan kecepatan antara lain kondisi lingkungan jalan, kemampuan pengendara, dan kondisi kendaraan (Shinar, 2007). Oleh sebab itu dibutuhkan perangkat manajemen kecepatan yang bertujuan untuk mengurangi insiden mengemudi terlalu cepat, dan untuk memaksimalkan kepatuhan terhadap batas kecepatan (Howard et al., 2008)

Rambu Lalu Lintas adalah bagian perlengkapan jalan yang berfungsi sebagai perintah, larangan, peringatan, atau petunjuk bagi pengguna jalan (Peraturan Menteri Perhubungan Republik Indonesia Nomor 13, 2014). Rambu batas kecepatan merupakan salah satu perangkat manajemen kecepatan yang dipasang sebagai upaya untuk mereduksi kecepatan kendaraan yang melintas pada suatu ruas jalan (Murti \& Muthohar, 2012). Rambu lalu lintas akan efektif apabila dipasang sesuai dengan standar teknis dan kajian manajemen lalu lintas (Budiharjo \& Yunarto, 2019)

Perangkat manajemen kecepatan yang telah terpasang di Ruas Jalan Perintis Kemerdekaan adalah rambu batas kecepatan maksimal yaitu $50 \mathrm{~km} / \mathrm{jam}$. Namun, belum efektif untuk dapat menurunkan kecepatan kendaraan bermotor yang melintas di ruas jalan tersebut. Tujuan penelitian ini adalah untuk menganalisis efektivitas rambu batas kecepatan yang sudah terpasang dan merekomendasikan pemasangannya.

Perbedaan penelitian ini dengan penelitian terdahulu adalah penelitian mengenai efektivitas rambu eksisting pembatasan kecepatan dan melakukan analisis penerapan rambu batas kecepatan berulang untuk meningkatkan efektivitas rambu batas kecepatan dan mewujudkan keselamatan jalan. Keselamatan jalan adalah suatu keadaan terhindarnya setiap orang dari risiko kecelakaan selama berlalu lintas yang disebabkan oleh manusia, kendaraan, jalan, dan/atau lingkungan (Undang-Undang Republik Indonesia Nomor 22, 2009) 


\section{Metode}

Penelitian ini dilakukan di Jalan Perintis Kemerdekaan, Kabupaten Cilacap yang merupakan jalan 4/2 terbagi. Pengambilan data kecepatan kendaraan eksisting dilakukan di kedua arah dengan jumlah sampel yang diambil dari data volume lalu lintas tertinggi di kedua arah pada Jalan Perintis Kemerdekaan. Pengukuran kecepatan kendaraan dilakukan pada 50 meter sebelum dan 50 meter sesudah melewati rambu batas kecepatan eksisting untuk melihat ada atau tidaknya penurunan kecepatan kendaraan. Survei kecepatan menggunakan metode Spot Speed dan dilakukan pada saat off peak. Spot Speed adalah kecepatan kendaraan pada waktu melewati satu titik tertentu pada jalan (Alamsyah, 2013)

Simulasi pemasangan rambu batas kecepatan berulang dilakukan pada jalur yang memiliki karakteristik kecepatan paling tinggi agar dapat dijadikan perbandingan yang lebih baik. Simulasi pemasangan rambu berulang dilakukan pada jarak 15 meter, 20 meter, 25 meter, 30 meter, 35 meter, 40 meter, 45 meter, dan 50 meter untuk mengetahui jarak pengulangan rambu batas kecepatan yang paling efektif. Pengukuran kecepatan kendaraan saat simulasi dilakukan 50 meter sebelum melewati rambu eksisting dan 50 meter sesudah melewati pengulangan rambu batas kecepatan. Alat yang digunakan dalam simulasi adalah 1 buah rambu bekas yang sudah dimodifikasi sesuai dengan aturan pemasangan rambu, kemudian Speed Gun untuk mengukur kecepatan kendaraan. Survei kecepatan menggunakan metode Spot Speed dan dilakukan pada saat off peak.

Analisis data dilakukan dengan menggunakan dua metode berikut:

1. Uji Paired Sample T-test

Digunakan untuk membandingkan selisih dua mean dari dua sampel yang berpasangan dengan asumsi data berdistribusi normal.

Dasar pengambilan keputusan:

a. Jika nilai (.Sig) > 0,05 maka tidak ada perbedaan yang signifikan

b. Jika nilai (.Sig) < 0,05 maka terdapat perbedaan

2. Analisis Efektivitas

Dilakukan dengan metode $\mathrm{N}$-gain Score untuk mengetahui efektivitas penggunaan suatu metode atau perlakuan (treatment) tertentu dalam penelitian one group pretest posttest design (Hake, 1999)

$$
\mathrm{N} \text { Gain }=\frac{\text { Skor Posttest-Skor Pretest }}{\text { Skor Ideal-Skor Pretest }}
$$

Dalam penelitian ini, rumus diatas disesuaikan dengan data penelitian.

a. Posttest $=$ diinterpretasikan menjadi data kecepatan after atau data kecepatan setelah simulasi 
b. Pretest = diinterpretasikan menjadi data kecepatan before atau data kecepatan kendaraan sebelum melewati rambu eksisting

c. Skor ldeal = diinterpretasikan menjadi target kecepatan yaitu batas kecepatan maksimal $50 \mathrm{~km} / \mathrm{jam}$

Adapun pembagian kategori perolehan nilai $\mathrm{N}$-Gain Score apabila nilai $\mathrm{g}>0,7$ maka dikategorikan tinggi, jika 0,3 $\mathrm{g} \leq 0,7$ maka dikategorikan sedang, dan jika $\mathrm{g}<$ 0,3 maka dikategorikan rendah (Yusuf, 2018)

Kategori perolehan nila N-Gain Score dalam \% apabila < 40\% maka ditafsirkan tidak efektif, jika 40\% - 55\% ditafsirkan kurang efektif , jika 56\%-75\% maka ditafsirkan cukup efektif dan apabila $>76 \%$ maka ditafsirkan efektif (Raharjo, 2019)

Penentuan jumlah sampel kendaraan ditentukan berdasarkan volume lalu lintas tertinggi pada kedua arah dengan tingkat ketelitian 5\%. Jumlah sampel kendaraan pada arah Selatan ke Utara sebanyak 301 sampel kendaraan sepeda motor, 213 sampel kendaraan ringan, dan 37 sampel kendaraan berat. Kemudian jumlah sampel kendaraan pada arah Utara ke Selatan sebanyak 331 sampel kendaraan sepeda motor, 239 sampel kendaraan ringan, dan 30 sampel kendaraan berat.

\section{Hasil dan Pembahasan}

\section{Hasil}

1. Kecepatan Eksisting Kendaraan

Kecepatan eksisting kendaraan pada arah Selatan ke Utara.

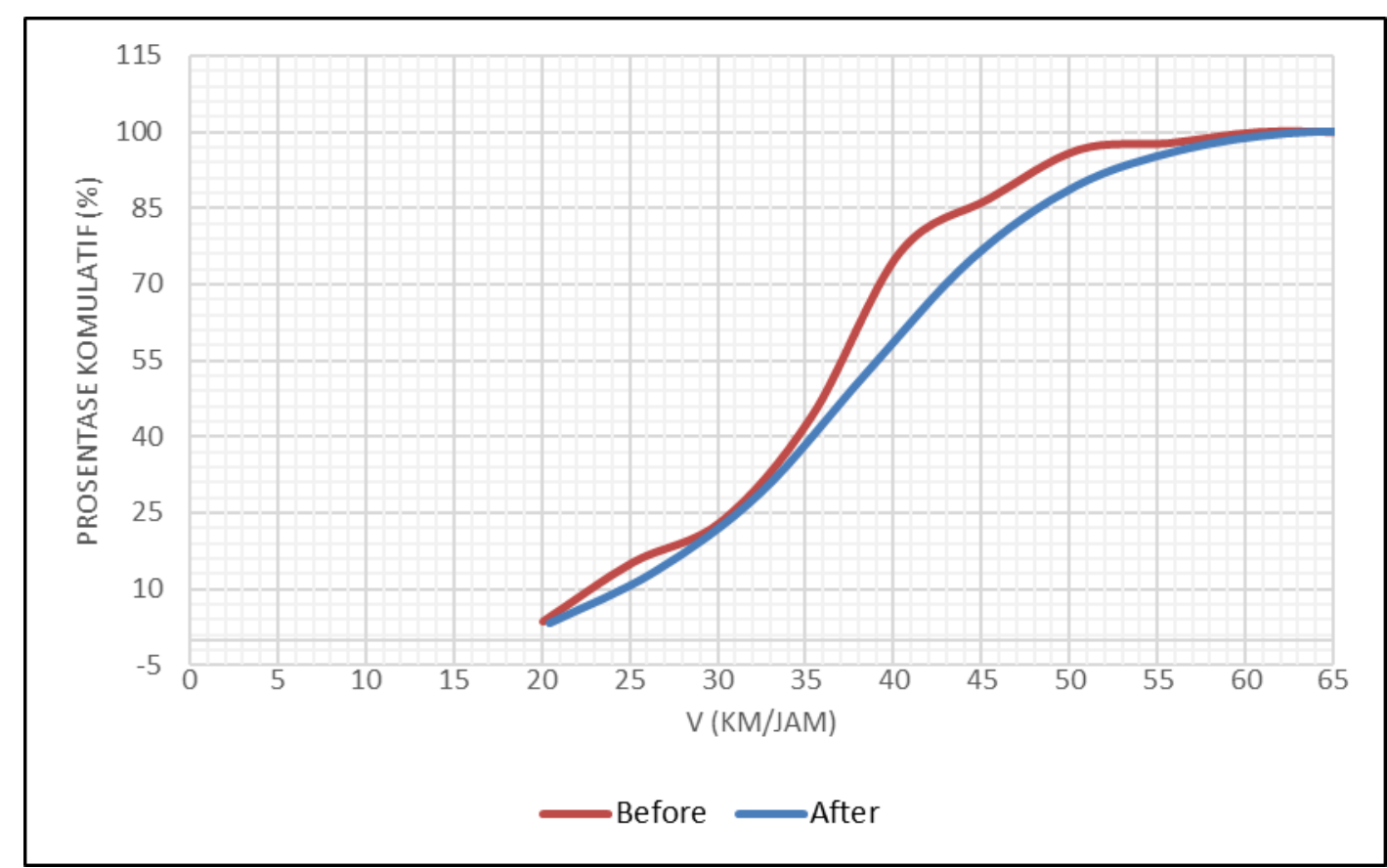

Gambar 1. Kecepatan Persentil 85 Sebelum Dan Sesudah Melewati Rambu Eksisting Arah Selatan Ke Utara 


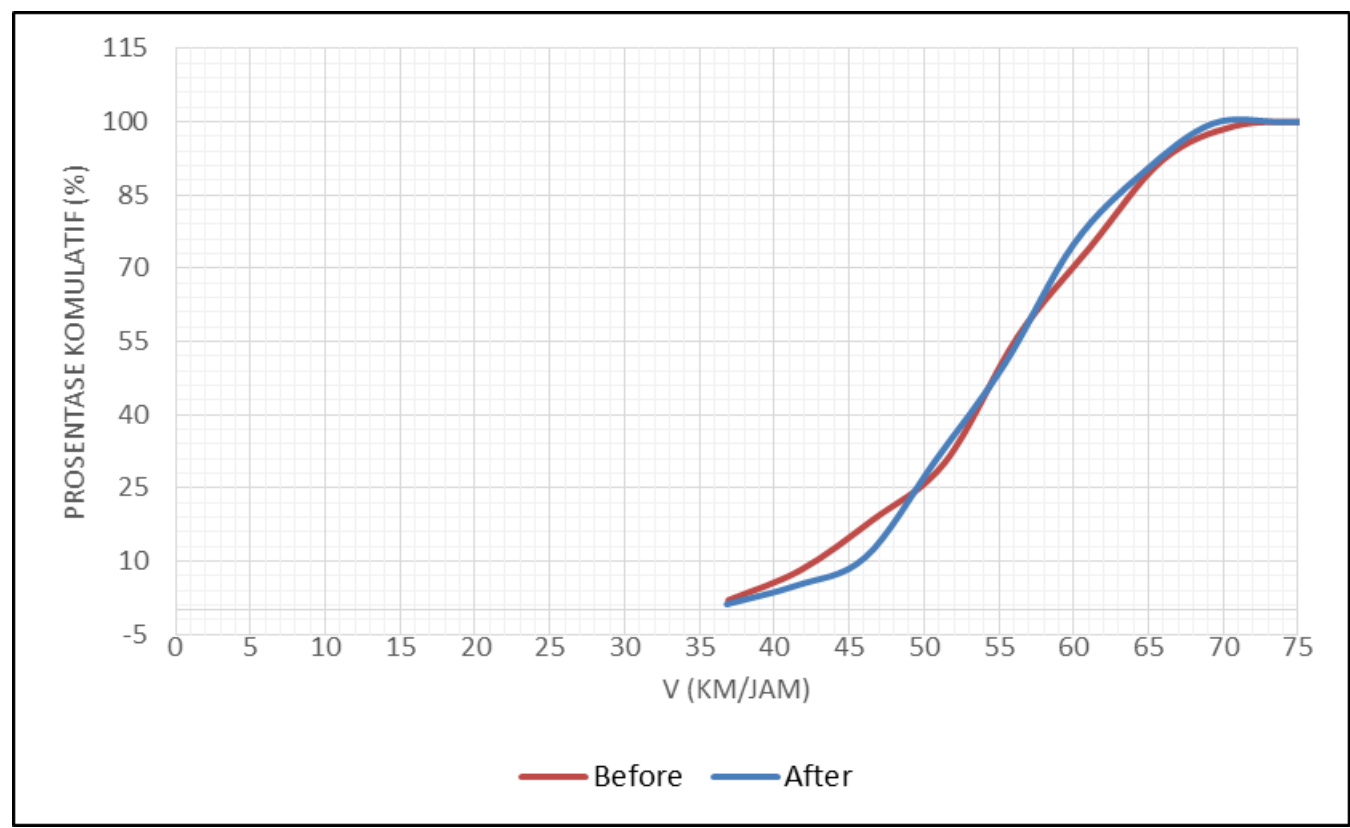

Gambar 2. Kecepatan Persentil 85 Sebelum Dan Sesudah Melewati Rambu Eksisting Arah Utara Ke Selatan

2. Kecepatan Kendaraan Saat Simulasi Pengulangan Rambu

Simulasi pemasangan rambu batas kecepatan berulang dilakukan di jalur yang memiliki karakteristik kecepatan paling tinggi yaitu arah Utara ke Selatan. Kecepatan Persentil 85 kendaraan saat simulasi pemasangan pengulangan rambu dapat dilihat pada Gambar 3

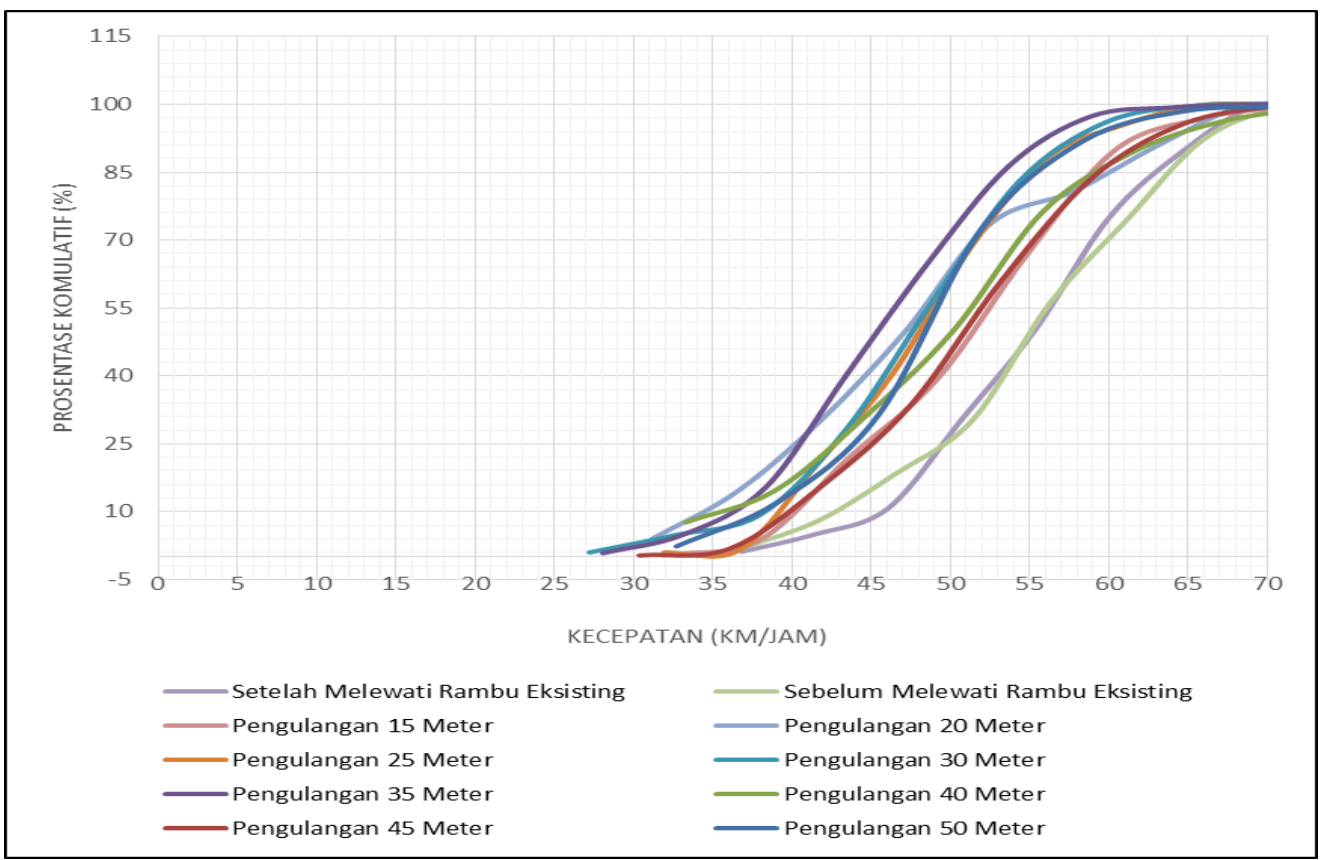

Gambar 3. Kecepatan P-85 Kendaraan Saat Simulasi Pengulangan Rambu 


\section{Hasil Analisis Keseluruhan Data}

Dari hasil analisis, rambu batas kecepatan maksimal yang telah terpasang menurunkan rata-rata kecepatan kendaraan, namun belum mencapai target yang diinginkan yaitu batas kecepatan maksimal $50 \mathrm{~km} / \mathrm{jam}$. Maka dilakukan simulasi pemasangan rambu batas kecepatan berulang.

Hasil analisis menunjukkan, terdapat penurunan rata-rata kecepatan kendaraan di semua jarak pengulangan rambu yang disimulasikan. Hasil analisis keseluruhan data pada saat simulasi pemasangan rambu batas kecepatan berulang dapat dilihat pada Tabel 1.

Tabel 1 Hasil Analisis Keseluruhan Data Saat Simulasi

\begin{tabular}{lccccc}
\hline \multicolumn{1}{c}{ Titik Penelitian } & $\begin{array}{c}\text { Kecepatan } \\
\text { P-85 }\end{array}$ & $\begin{array}{c}\text { Hasil Paired } \\
\text { Sample T-Test }\end{array}$ & $\begin{array}{c}\text { Nilai N- } \\
\text { Gain }\end{array}$ & Kategori & Tafsiran \\
\hline $\begin{array}{l}\text { Sebelum melewati } \\
\text { rambu eksisting }\end{array}$ & $66 \mathrm{~km} / \mathrm{jam}$ & & & & \\
\hline $\begin{array}{l}\text { Setelah melewati } \\
\text { rambu eksisting }\end{array}$ & $65 \mathrm{~km} / \mathrm{jam}$ & $\begin{array}{c}\text { Tidak ada } \\
\text { perbedaan }\end{array}$ & 0,06 & Rendah & $\begin{array}{c}\text { Tidak } \\
\text { efektif }\end{array}$ \\
\hline $\begin{array}{l}\text { Pengulangan } \\
\text { Rambu Jarak } 15 \mathrm{~m}\end{array}$ & $60 \mathrm{~km} / \mathrm{jam}$ & Ada perbedaan & 0,38 & Sedang & $\begin{array}{c}\text { Tidak } \\
\text { efektif }\end{array}$ \\
\hline $\begin{array}{l}\text { Pengulangan } \\
\text { Rambu Jarak } 20 \mathrm{~m}\end{array}$ & $63 \mathrm{~km} / \mathrm{jam}$ & $\begin{array}{c}\text { Tidak ada } \\
\text { perbedaan }\end{array}$ & 0,19 & Rendah & $\begin{array}{c}\text { Cukup } \\
\text { efektif }\end{array}$ \\
\hline $\begin{array}{l}\text { Pengulangan } \\
\text { Rambu Jarak } 25 \mathrm{~m}\end{array}$ & $56 \mathrm{~km} / \mathrm{jam}$ & Ada perbedaan & 0,62 & Sedang & $\begin{array}{c}\text { Cukup } \\
\text { efektif }\end{array}$ \\
\hline $\begin{array}{l}\text { Pengulangan } \\
\text { Rambu Jarak } 30 \mathrm{~m}\end{array}$ & $60 \mathrm{~km} / \mathrm{jam}$ & Ada perbedaan & 0,38 & Sedang & $\begin{array}{c}\text { Tidak } \\
\text { efektif }\end{array}$ \\
\hline $\begin{array}{l}\text { Pengulangan } \\
\text { Rambu Jarak } 35 \mathrm{~m}\end{array}$ & $54 \mathrm{~km} / \mathrm{jam}$ & Ada perbedaan & 0,75 & Tinggi & $\begin{array}{c}\text { Cukup } \\
\text { efektif }\end{array}$ \\
\hline $\begin{array}{l}\text { Pengulangan } \\
\text { Rambu Jarak } 40 \mathrm{~m}\end{array}$ & $61 \mathrm{~km} / \mathrm{jam}$ & Ada perbedaan & 0,31 & Sedang & $\begin{array}{c}\text { Tidak } \\
\text { efektif }\end{array}$ \\
\hline $\begin{array}{l}\text { Pengulangan } \\
\text { Rambu Jarak } 45 \mathrm{~m}\end{array}$ & $65 \mathrm{~km} / \mathrm{jam}$ & $\begin{array}{c}\text { Tidak ada } \\
\text { perbedaan }\end{array}$ & 0,06 & Rendah & $\begin{array}{c}\text { Tidak } \\
\text { efektif }\end{array}$ \\
\hline $\begin{array}{l}\text { Pengulangan } \\
\text { Rambu Jarak } 50 \mathrm{~m}\end{array}$ & $58 \mathrm{~km} / \mathrm{jam}$ & Ada perbedaan & 0,50 & Sedang & $\begin{array}{c}\text { Kurang } \\
\text { efektif }\end{array}$ \\
\hline
\end{tabular}

Sumber: Hasil Analisis, 2020

\section{Pembahasan}

Dari hasil analisis, rambu batas kecepatan yang sudah terpasang dapat menurunkan kecepatan kendaraan, namun belum efektif dikarenakan belum mencapai target yaitu batas kecepatan maksimal $50 \mathrm{~km} / \mathrm{jam}$. Pemasangan rambu batas kecepatan secara berulang diharapkan dapat meningkatkan efektivitas rambu batas kecepatan dalam mereduksi kecepatan kendaraan bermotor. Kecepatan rata-rata kendaraan menunjukkan penurunan kecepatan pada setiap jarak pengulangan rambu yang disimulasikan. Hal ini sudah sesuai dengan penelitian sebelumnya (Farizaldin et al., 2018);(Hasibuan et al., 2018). Berkendara melebihi batas kecepatan lebih sering terjadi apabila tidak dilakukan pengulangan rambu batas kecepatan. Ketika pengemudi tidak diingatkan batas kecepatan, maka kecepatan kendaraan secara linear akan meningkat pada seluruh segmen (Jongen et al., 2011). 


\section{Jarak Pandang Henti}

Jarak pandang henti dapat digunakan untuk menemukan jarak reaksi atau jarak pengemudi merespon dan mengambil keputusan suatu rintang yang ada di depannya. Jarak pandang henti merupakan penjumlahan dua bagian jarak yaitu jarak reaksi dan jarak pengereman. Waktu yang dibutuhkan untuk bereaksi mengambil keputusan disebut waktu PIEV (Perception, Identification, Emotion, Volition). Jadi waktu PIEV adalah waktu yang dibutuhkan untuk proses deteksi, pengenalan dan pengambilan keputusan. Waktu ini dipengaruhi dari kondisi pengemudi, kebiasaan, cuaca, penerangan juga kondisi dari mental pengemudi. Waktu ini diperkirakan sekitar 1,5 detik (Fred L. Mannering, 2018). Setelah pengambilan keputusan untuk menginjak rem, maka pengemudi memerlukan waktu sampai ia menginjak rem. Waktu itu memerlukan sekitar 0,5 sampai 1 detik. Untuk perencanaan diambil waktu 1 detik. Maka waktu yang dibutuhkan sekitar 2,5 detik (Bina Marga, 1997) Pada penelitian ini, jarak yang digunakan untuk acuan adalah jarak reaksi dengan perhitungan sebagai berikut:

$$
\begin{gathered}
D p=\frac{V \times t}{3,6} \\
D p=\frac{50 \times 2,5}{3,6} \\
=34,722 \approx 35 \text { meter }
\end{gathered}
$$

Dimana: Dp = jarak PIEV (Perception, Identification, Emotion, and Volition)

$\mathrm{V}=$ kecepatan rencana

$\mathrm{t}=$ = total waktu persepsi dan reaksi (detik)

Berdasarkan hasil perhitungan menggunakan jarak pandang henti diatas, didapatkan hasil 35 meter sebagai jarak yang dapat digunakan untuk pemasangan rambu secara berulang. Hasil perhitungan tersebut sesuai dengan hasil analisis bahwa jarak pemasangan rambu batas kecepatan berulang yang paling efektif adalah pada jarak 35 meter.

\section{Pemrosesan Informasi Pada Manusia}

Short-term memory berhubungan dengan apa yang sedang difikirkan seseorang ketika menerima stimulus dari lingkungan. Durasi suatu informasi short-term memory adalah 15-20 sekon, dan dapat meningkat hinggan 20 menit apabila terdapat pengulangan informasi (Shinar, 2007) Teori inilah yang mendasari dilakukannya penelitian simulasi pemasangan rambu batas kecepatam secara berulang. Hasil analisa menunjukan bahwa terdapat penurunan kecepatan kendaraan dengan pemasangan rambu batas kecepatan berulang, yang artinya semakin sering pengulangan rambu terjadi maka durasi penyimpanan informasi akan batas kecepatan juga akan semakin lama sehingga 
kepatuhan terhadap batas kecepatan maksimal dapat meningkat.

Penelitian yang sudah dilakukan adalah pengaruh tanda pengulangan dan gangguan terhadap kecepatan (Jongen et al., 2011) di Belgia dengan menggunakan driving simulator. Hasilnya adalah gangguan berupa visual maupun kognitif pada pengemudi menurunkan kecepatan mengemudi. Batas kecepatan lebih sering dilanggar ketika tanda-tanda batas kecepatan diulang lebih jarang. Ketika pengemudi tidak diingatkan batas kecepatan, kecepatan secara linear meningkat di seluruh segmen. Peningkatan kecepatan paling besar terjadi ketika belum ada pengulangan batas kecepatan sama sekali. Hal ini telah sesuai dan selaras dengan teori dan penelitian sebelumnya.

\section{Kesimpulan}

Dari hasil analisis yang dilakukan, maka dapat disimpulkan bahwa rambu batas kecepatan yang telah terpasang memiliki efektivitas sebesar 6,25\%. Simulasi pemasangan jarak pengulangan rambu batas kecepatan yang paling efektif adalah pada jarak 35 meter dengan efektivitas sebesar 75\% dan kecepatan persentil-85 sebesar $54 \mathrm{~km} / \mathrm{jam}$, hampir mendekati target kecepatan yaitu $50 \mathrm{~km} / \mathrm{jam}$. Maka direkomendasikan untuk pemasangan rambu batas kecepatan berulang dengan jarak 35 meter.

\section{Daftar Pustaka}

Alamsyah. (2013). Rekayasa Lalu Lintas. In Journal of Chemical Information and Modeling (Vol. 53, Issue 9). https://doi.org/10.1017/CBO9781107415324.004

Bina Marga. (1997). Tata Cara Perencanaan Geometrik Jalan Antar Kota. 038, 54.

Budiharjo, A., \& Yunarto, I. F. (2019). Study on Improving the Safety of the Crossroads. Jurnal Keselamatan Transportasi Jalan, 15-37.

Farizaldin, M., AS, S., \& Suyono, R. S. (2018). Studi Tentang Efektivitas Alat Pengendali Kecepatan Pada Kawasan ZoSS di Kota Pontianak. Mahasiswa Teknik Sipil Universitas Tanjungpura, 5(2), 1-15.

Fred L. Mannering, S. S. W. (2018). Principles Of Highway Engineering and Traffic Analysis. In John WIIley \& Sons, Inc.: Vol. Fifth Edit.

Hake, R. R. (1999). Analyzing Change/Gain Score. Indiana University.

Hasibuan, H. S., Harmain, R., Berkademi, W., \& Sari, I. P. (2018). Daya Dukung Kawasan Transit Oriented Development Di Lebak Bulus Provinsi Dki Jakarta. Jurnal Plano Madani, 7, 174-184.

Howard, E., Mooren, L., Nilsson, G., Quimby, A., \& Vadeby, A. (2008). Manajemen kecepatan.

Peraturan Menteri Perhubungan Republik Indonesia Nomor 111, (2015). 
Undang-Undang Republik Indonesia Nomor 22, 7 Sekretariat Negara 1 (2009). https://doi.org/10.1029/2008GB003237

Jongen, E. M. M., Brijs, K., Mollu, K., Brijs, T., \& Wets, G. (2011). 70 km/h speed limits on former $90 \mathrm{~km} / \mathrm{h}$ roads: Effects of sign repetition and distraction on speed. Human Factors, 53(6), 771-785. https://doi.org/10.1177/0018720811419848

Kawulur, C. I., Sendow, T. K., Lintong, E., \& Rumayar, A. L. E. (2013). Analisa Kecepatan Yang Diinginkan Oleh Pengemudi (Studi Kasus Ruas Jalan Manado-Bitung). Jurnal Sipil Statik, 1(4), 289-297.

Murti, R. T., \& Muthohar, I. (2012). Evaluasi Kinerja Rambu Pembatasan Kecepatan Sebagai Upaya Mendukung Aksi Keselamatan Jalan. Teknik Sipil Dan Lingkungan, Universitas Gadjah Mada, 12(3), 227-236.

Peraturan Menteri Perhubungan Republik Indonesia Nomor 13, (2014).

Raharjo, S. (2019). Cara Menghitung N-Gain Score Kelas Eksperimen dan Kontrol dengan SPSS. SPSS Indonesia. https://www.spssindonesia.com/2019/04/cara-menghitung-n-gain-scorespss.html

Romadhona, P. J., dan Ramdhani, S., (2017). Pengaruh Kecepatan Kendaraan Terhadap Keselamatan Pengguna Kendaraan Bermotor Pada Simpang Tak Bersinyal. Rekayasa Sipil, 11(1), 31-40.

Shinar, D. (2007). Taffic Safety and Human Behavior. In Elsevier (First, Vol. 53, Issue 9). Elsevier. https://doi.org/10.1017/CBO9781107415324.004

Yusuf, M. (2018). Efektivitas Perangkat Pembelajaran Berbasis Keterampilan Proses untuk Meningkatkan dari Kemampuan Akademik. Jurnal Pendidikan, 3833, 115. 